\title{
Cell Therapy Assistance in Reconstructive Surgery for Musculoskeletal Tissues Following Burn and Trauma: Swiss Cellular Transplantation Platform
}

\author{
Anthony de Buys Roessingh ${ }^{1}$, Samia Guerid ${ }^{2}$, Yok-ai Que ${ }^{3}$, Mette Berger ${ }^{3}$, Nathalie Hirt-Burri², Corinne Scaletta ${ }^{2}$, Wassim Raffoul ${ }^{2}$ and \\ Lee Applegate ${ }^{2 *}$
}

${ }^{1}$ Service of Pediatric Surgery

${ }^{2}$ Plastic and Reconstructive Surgery, Unit of Regenerative Medicine

Intensive Medicine

University Hospital of Lausanne, Switzerland

\begin{abstract}
Health issues for severe burns and trauma affecting populations from both civilian and military can have many similarities. Much of the medical progress for treatment and surgical care has been documented during times of catastrophic events and war. Death and morbidity of military personnel due to blast and combat-related injuries has declined as a result of improved surgical management, faster transport, and the use of antibiotics. Integration of cellular therapies could aid in repairing damaged tissues more rapidly. As bio-engineered cells and materials would be readily available, they could rapidly be used in the military settings, especially for the treatment of burns and trauma. Cell sources that can be easily expanded and stocked (allogenic sources) would be interesting cell sources to have developed to avoid the biopsy from the patient and the time necessary to prepare the cells before treatment. Cel sources can originate from both animal and human and at all periods of development extending from embryonic to adult. Cell sources can be technically demanding or they can be developed from primary tissue and the resulting cells can remain more similar to their original state. The use of progenitor cells have been developed in a unique Federal Transplantation Program Registration in Switzerland (cell lines have been described and deposited in the European Protection Agency Cell Depository, Porton Down's) should help to advance cellular therapy programs with qualified material that is available when needed for both soft and hard tissues that have been injured. We will give an overview of: i) cell therapies used in military practice to date; ii) Description of cell types and cell choices for regenerative medicine; and iii) The organization of the progenitor cell therapy platform in Switzerland; iv) Pre-requisite recommendations for the future of using cell therapies in world defense and human security.
\end{abstract}

Keywords: Stem cells; Burns; Musculoskeletal medicine; Progenitor cells; Transplantation; Cell bank; Mesenchymal stem cell; Military; Battlefield dressing; Hemostatic dressing; Antimicrobial; Infection; Corpsman; Improvised explosive device; Triage

Abbreviations: BM-MSC: Bone Marrow-Mesencymal Stem Cell; DOD: Department of Defence; AFIRM-Armed Forces Institute of Regenerative Medicine; GvHD: Graft versus Host Disease; MCB: Master Cell Bank; WCB: Working Cell Bank; GMP: Good Manufacturing Practice; IED: Improvised Explosive Device

\section{Introduction}

Major injuries incurred from explosive sources in recent military interventions have caused high interest in new tissue regenerative options. Historically, much progress in plastic surgery techniques for burn and trauma management have been during intensive war periods $[1,2]$. Now it is known that many supplementary issues need to be addressed before tissue reconstruction including management of pain, nutrition, infection, and physiological function. The latter needs to be managed by topical biological cover in large surface tissue damage to avoid fluid losT. Once available through National Tissue Banks, cadaver skin used in the life-saving treatments of burn patients is now difficult to access. The first wide use of allogenic cadaver skin was in World War II. Alternative sources from humans and animals that are conserved frozen or in glycerol are used routinely [3]. Conservation techniques using frozen tissues can be appropriate for civilian use but could be more difficult for military due to availability of freezers on-site. Alternative sources of organs and tissues with their specific conservation, along with the development of modern regenerative medicine techniques, could help assure quality and security for the patient. The possible role of stem cells in military medicine has been highly funded by the US Department of Defense (DOD) through the Armed Forces Institute of Regenerative Medicine (AFIRM) program in past. The recent conflicts in Iraq and Afghanistan have increased the intensity of medical research in the military and new DOD proposal calls will certainly open many new avenues for cellular therapy.

\section{Cell Therapies used in Military Practice}

Many advances in cell therapies have already been made due to tax-payer funded research through the AFIRM program to develop new treatments using cell therapies and advanced plastic surgery. Already in 1997, the DOD awarded 224.7 million dollars to develop cell banked sources of bone marrow derived stem cells (BM-MSC) to study radiation sickness in collaboration with Osiris Therapeutics and Genzyme (www.osiris.com; www.genzyme.com). The same source of cells was to be used also for meniscus cartilage regeneration at that time. The cell therapy was based on adult donors (18-30 years) of bone marrow where cells were isolated by density gradient and

*Corresponding author: Prof. Lee Ann Laurent-Applegate, Unit of Regenerative Therapy, Service of Plastic and Reconstructive Medicine, Department of Musculoskeletal Medicine, Switzerland, Tel: ++41 21 3143510; Fax : ++41 21887 84 14; E-mail: Lee.Laurent-Applegate@chuv.ch

Received March 19, 2013; Accepted March 23, 2013; Published March 30, 2013

Citation: de Buys Roessingh A, Guerid S, Que Y, Berger M, Hirt-Burri N, et al. (2013) Cell Therapy Assistance in Reconstructive Surgery for Musculoskeletal Tissues Following Burn and Trauma: Swiss Cellular Transplantation Platform Def Manag S3: 003. doi:10.4172/2167-0374.S3-003

Copyright: @ 2013 de Buys Roessingh A, et al. This is an open-access article distributed under the terms of the Creative Commons Attribution License, which permits unrestricted use, distribution, and reproduction in any medium, provided the original author and source are credited. 
purified by adhesion to eliminate non-MSC cell sources. The cultured resulting cells from one donor were to make a stock of 10,000 doses of final product called Prochymal ${ }^{\circledR}$ to counter nuclear terrorism and other radiological incidents. How the cells are cultured will ultimately affect how they will perform. Unfortunately, in the early study with these stocked BM-MSC's, the cells were expanded over numerous passages that may have made the cells lose their effectiveness from over manipulation. The use of this product in many clinical studies on Graft $v s$. Host Disease has not shown positive significant clinical results but this may be also related to patient populations chosen [4-6].

These cells are being investigated for clinical results in other diseases (GvHD, Crohn's disease, cardiology, diabetes, pulmonary disease, multiple sclerosis, acute organ rejection, scleroderma and arthritis) by Osiris [7]. The DOD and AFIRM have recently awarded a grant in Miami this year (http://med.miami.edu/news/miller-schoolphysician-scientists-receive-3-million-defense-grant-to-treat/) to conduct the first clinical trials on burns and wounds with the BMMSC cells and to also look at combined surgical laser techniques with the stem cells in third degree burn scar treatments and management. In optimizing the cell culture procedure (learning from that of the past experience with Prochymal ${ }^{\circledR}$ ), these allogenic cell sources could possibly be interesting for treating burns and wounds to have readily available stocks of frozen cells.

Other applications that the military is investigating are devices that can be used with individualized kits such as for autologous transplantation of BM-MSC. By having a centrifuge that is adapted to closed-system tubes for blood and bone marrow collection, these could be used directly at the site for patient care (www.arteriocyte.com/). The autologous platelet gel that is obtained has the intention of use to improve skin graft acceptance and adherence with supposed action of providing beneficial growth factors and antimicrobial protection for graft survival. Although autologous cell therapies are adapted to the individual patient, BM procedures are invasive and painful. Other platelet rich preparations can be from whole blood instead of bone marrow. Platelet enriched Plasma (PRP) is blood plasma that has been enriched with platelets through centrifugation and concentration. PRP is less invasive and could be used with the kits for on-site patient treatment and have been shown to be beneficial in recent clinical activity for wound and burn management [8]. In recent clinical work with the Dutch Armed Forces, the Australian Defence Force (ADF) has been using special cryo-preserved platelets for treatment of patients in Afghanistan. This technique was developed over 30 years ago with the US Navy and originally used in clinical work during heart surgery. In their experience, they had seen that the frozen platelets were linked to fewer adverse events, reduced bleeding more rapidly and reduced the total amount of blood required for transfusion [9].

In 2008, AFIRM awarded top hospitals and universities $\sim 300$ million dollars to develop new treatments using cell science and advanced plastic surgery which have included research on many musculoskeletal tissues (i.e. skin, muscle, cartilage, bone and tendon). Massachusetts General Hospital has been developing bioengineered ears for soldiers that have lost this appendage in combat. They used computer modeled ears or the patient, crafted titanium framework covered in collagen and the patient's own cartilage cells that have been harvested from either the nose o\$tibs to seed into the ear scaffold and Dr. Sundback has mentioned how amazing progress has been possible due to AFIRM funding [10,11]. Other developments are biological scaffolds to help patients cells integrate into new tissue formation. Extracellular matrix derived from pig intestine has been developed to prepare muscle grafts in both former military troops and non-military patients [12].

AFIRM is also at the lead to bring foreign developed techniques for direct use in clinical trials in the USA. Efforts to make enough skin for severe burns have been shown to be possible in a technique developed in Australia with a special sprayer device and kit that allows to take a $2-4 \mathrm{~cm}$ skin biopsy from the patient and process it in the operating room directly within less than one hour and then to apply the patient cells by spraying onto burns and wounds $[13,14]$. Alternatively, foreskin tissue from circumcision has been assessed with this device to provide off-the-shelf cell sources ready for use. In a recent clinical study program, foreskin tissue cells which have been immortalized have been used for burns and wounds. These cells are bioengineered to make fresh artificial skin which has been compared to cryopreserved cadaver skin for traumatic wound cover and has been shown to be welltolerated in the clinic [15]. Importantly, these transformed cells near diploid keratinocytes have been shown to be pathogen-free, consistent and do not form tumors even though they spontaneously mutated. Other clinical trials that are funded by the DOD are concentrated adipose tissue and stem cells for restoring facial features in craniofacial trauma [16]. Many autologous and now allogenic cell therapies are being intensively investigated particularly for musculoskeletal tissue regeneration and new techniques to stabilize end-products such as freezing and lyophlization are being adapted to assist in logistics and to have availability on the battle-field.

\section{Cell Types and Choice for Regenerative Medicine}

The term stem cell is vast in definition and there are different stem cell types which are related to the tissue of origin and stage of development (Figure 1). Importantly, technical aspects necessary to isolate and direct stem cells to specific cell types eventually desired will ultimately decide which cell choices are better adapted for future clinical practice.

\section{Embryonic stem cells}

Embryonic stem cells are able to create a wide range of cell types, but in order to be able to create these different cells they have to be taken at an early age of the embryo (around five days after ovum fertilization). Five days after ovum impregnation the "blastocyte" is created and embryonic stem cells can be obtained (Figure 1). Specifically, these embryonic stem cells are "totipotent" until about eight cells and it is only afterwards that they become pluripotent which means that they cannot develop into another embryo but they can develop in all different types of cells (approximately 2 weeks post-fertilization). Taken together, these cells are considered as an embryo until about eight weeks after fertilization. From that point on, the embryo is designated as a foetus and the embryos are controlled under specific regulation for in vitro fertilization where in many countries a specific license is required to work with embryonic stem cells.

\section{Fetal cells and tissue}

At later stages of development (9-12 weeks of gestation), the tissue is considered under Transplantation programs as an organ donation and under the same regulation for adult stem cells (Figure 1). Fetal tissue can be considered to be an organ donation when from a voluntary pregnancy interruption and in Switzerland and many countries worldwide, there is legal availability of this medical procedure with trends remaining stable throughout the last two decades [17-19]. In the United States, the importance of having access to legal pregnancy interruptions has been brought to attention in women's public health issues recently. 
Citation: de Buys Roessingh A, Guerid S, Que Y, Berger M, Hirt-Burri N, et al. (2013) Cell Therapy Assistance in Reconstructive Surgery for Musculoskeletal Tissues Following Burn and Trauma: Swiss Cellular Transplantation Platform. J Def Manag S3: 003. doi:10.4172/2167-0374.S3-003

$\begin{array}{cccc}\text { Embryonic Stem } & \text { Embryonic Fetal } & \text { Fetal } & \text { Adult Stem } \\ \mathbf{0 - 2} \text { weeks } & 5-8 \text { weeks } & 9-14 \text { weeks } & \\ <100 \text { cells } & >1000 \text { cells } & >1,000,000 \text { cells } & \sim 1 \text { cell in every } 10^{4-5} \\ \text { (Totipotent) } & \text { (Pluripotent) } & \end{array}$

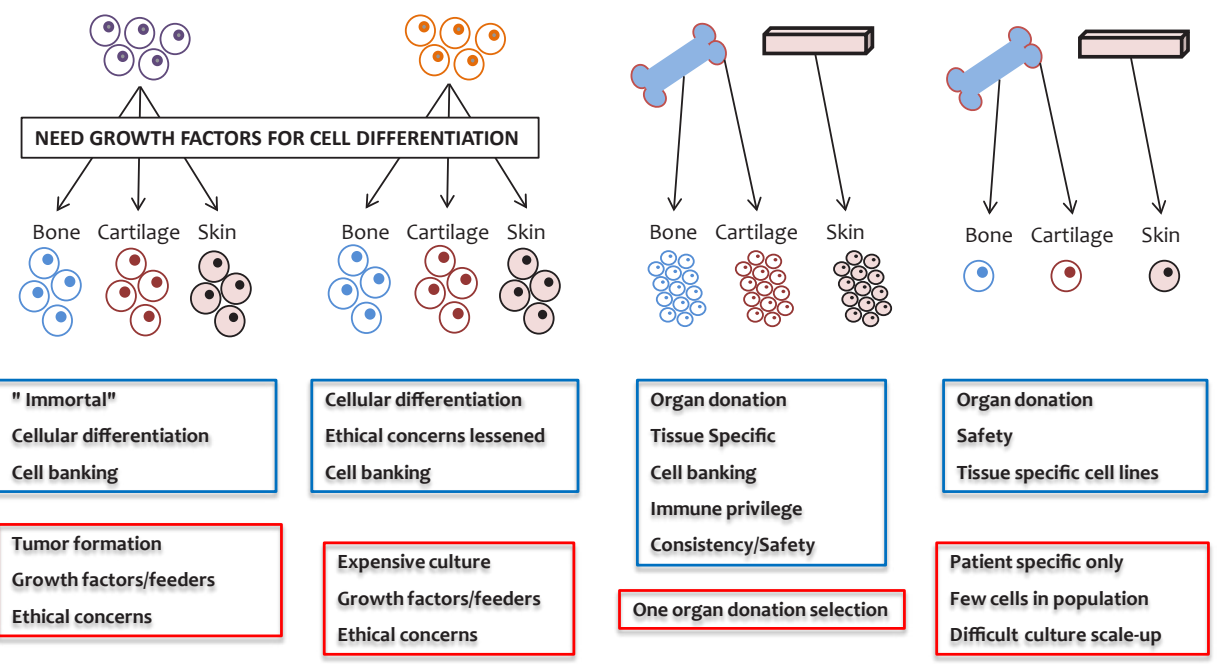

Figure 1: Cell types and cell choices for regenerative medicine.

Cells derived from tissue at the blastocyst stage are embryonic stem cells, totipotent but less than 100 cells to begin cell cultures. At 5-6 weeks of human development, the tissue is embryonic fetal and produces embryonic germ which are pluripotent cells and have more cells to begin cell culture ( $>1000)$. Organ specific cells are derived from 9-16 weeks of human fetal development and these cells have progenitor capacity which is that they cannot easily de-differentiate when the whole population is taken into account and there is a high number of cells $\left(>10^{6}\right)$ for culture establishment. Adult stem cells can be found within all tissue types (from 9 weeks of gestation on) and these mesenchymal stem cells can be pluripotent. However, only 1 stem cell is found in every $10^{4}-10^{5}$ cells in total specific tissue. Common tissues used in cell therapies to create cell lines in cell culture systems are bone marrow, adipose, placenta, amniotic fluid, retina, cornea and skin. Both positive (blue box) and negative (red box) factors are given for each specific cell type.

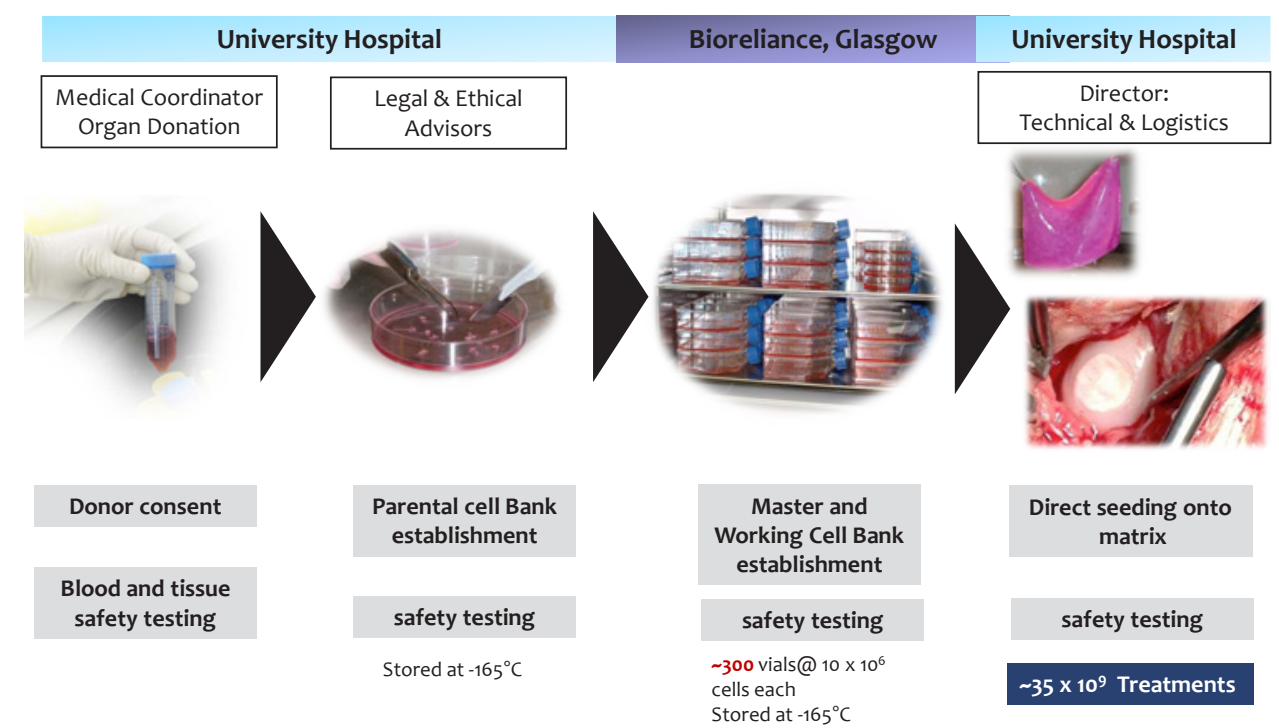

Figure 2: Organ Donation Program and Cell Bank Development.

Multiple fields of expertise are necessary to develop a successful platform for Organ Donations including lawyers to interpret regulatory issues of organ donations and defined therapeutic tissue and cellular products, biologists to assure the most appropriate cell choice and technical specifications, engineers for delivery and tissue engineering design and medical doctors for donor screening, informed consent and appropriate patient application of tissue and cellular products. One single organ donation may produce first a Parental Cell Bank (PCB) of primary cells. Tissue from skin $\left(1-2 \mathrm{~cm}^{2}\right)$ or from bone, cartilage, tendon and disc $\left(0.2-0.5 \mathrm{~mm} \mathrm{~m}^{3}\right)$ is enough to produce enough cells for further establishment of Master and Working Cell Banks (hundreds of vials each with $10 \times 10^{6}$ cells) that are frozen in liquid nitrogen $\left(-165^{\circ} \mathrm{C}\right)$ and can be kept for decades with high stability. From each of the Master Cell Bank vials, it is possible to make one Working Cell Bank containing hundreds of vials. Safety testing can be at each stage of development (patient to cell banking) before making final cell therapy treatments which can be as high as $35 \times 10^{9}$ for any given musculoskeletal tissue. 
As many as one in three women before the age of 45 seek this medical service. It has been proposed that abortion be integrated in primary care medicine and not only specialized clinics to assure the best health care [20].

Even though fetal cells are considered as adult stem cells, there can be certain considerations taken into account since this is associated with the voluntary interruption of pregnancy and to assure ethical use of available tissue donations. A specific platform has begun in Switzerland in 2008 for tracing all aspects of fetal tissue donation to assure complete transparency and respect of the Swiss laws and European regulations for tissue use (Figure 2) [21-28].

\section{Adult stem cells}

Adult stem cells can be isolated from blood tissue, bone tissue, nervous tissue, adipose tissue, skin, heart, and all other tissues of the body (Figure 1) but the donation must not be paid for and the tissue can come from either a living or deceased person. The advantage of adult stem cells is that neither the destruction of embryos nor a voluntary interruption of pregnancy is necessary. Several conditions must be filled in order to remove organs, tissues or cells from a deceased and only if: i) the person gave her/his consent before her/his death; and ii) the death has been determined (with applied local law).

For living donors, some conditions have to be filled in order to donate organs, tissues or cells and the person must: i) be over 18 and mentally competent; ii) has been informed comprehensively and has given free oral and written consent; iii) be free from severe risk for her/ his life or health; and, iv) know that the recipient cannot be treated by any other alternative and efficient therapy without comparable benefit. In addition, it is imperative that no sample be taken from a person who would not be capable of clear consent with exception in some conditions and finally the donor must have adequate health insurance.

Foreskin tissue from new-borns is also considered to be an organ donation and cellular derivatives as adult stem cells. The foreskin is often taken when the person is young and would be treated similar to extra operating room excess tissue, and destined to be destroyed once taken. Because this tissue contains fibroblasts which could be useful for skin regeneration, the oral and written consent from the legal representative could be given in order to use the foreskin tissue for purpose of research and clinical use [22].

\section{Technical considerations of cell choices}

The possibility to expand tissue in cell culture systems and have cell populations that retain original tissue properties has provided enormous possibilities in the transplantation and tissue engineering field. Cell therapies are not new in medical treatments as bone marrow transplantation has been used for therapeutic purposes for over 40 years. Newer cell therapies, whereby cells can be maintained outside the body in cell culture dishes and flasks and expanded to large quantities, were first used successfully for skin grafting and aiding the severely burned patient [29]. However, cells from the patient can take up to several weeks in culture in order to have enough cells for the first treatments. Therefore, other cell sources could be of particular importance in the management of severe trauma. One of the major challenges for assuring that more patients will benefit from cell-based therapies in the future will be the optimization of the choice of cell type as well as their isolation and proliferation.

Embryonic stem cells, adult and mesenchymal stem cells, and fetal progenitor cells can all be expanded in cell culture systems. These cells not only differ highly in their development but also in the complexity of cell culture and final delivery for the patient. Tissue choices from animal and human sources at all ages of development can be evaluated with advantages and disadvantages for each final cell type.

Embryonic stem cells that are isolated from early-stage embryo (Figure 1) present the particularity of being pluripotent and have an advantage over those cells from adult mesenchymal stem cells, which can differentiate only into a restricted number of cell lineages. However, cultures of both these stem cell types are technically very demanding because the amount of tissue to begin with is very low for embryonic stem cells ( $<100$ cells $)$ and isolation of adult mesenchymal stem cells from the tissue mass is difficult (only 1 stem cell for every $10^{4}$ ${ }^{5}$ cells in total adult tissue). Maintenance and expansion of stem cells in an undifferentiated state require the addition of many specific growth factors [30-33] and efficient culture of embryonic stem cells and some adult mesenchymal stem cells are not possible without feeder layers which are in some part responsible for the inconsistent colony cell growth. The necessity to use many exogenous growth factors as well as feeder layers to differentiate into specific cellular lineages are limiting factors for the scale-up of embryonic and adult stem cell cultures for clinical applications. There are other major issues with these stem cell types for security as the cells can de-differentiate once placed into an in vivo environment and even develop into tumors. Many techniques involving cell cloning or encapsulation have been utilized to date for assuring delivery of correct cell populations [34].

Unlike stem cells, fetal cells are differentiated cells with high expansion (Figures 1 and 2), regeneration and low immunogenic properties [31,35-38]. As the fetal cells are already differentiated and do not need to be directed, manipulated or altered, the vast number of additional growth factors normally necessary are not needed for cell culture and expansion. These cells are not known to de-differentiate once placed into the in vivo environment since they are originally from defined tissues. They produce uniform primary cultures of cells from tissue explants without specific cell selection during tissue processing $[32,33,39-42]$.

Establishment of cell banks is a crucial step in the process of many vaccines, medicinal products or tissue-engineering products and therefore the choice of cell-type is extremely important for technical and security reasons. Fetal cells, because of their rapid growth and stability, are of high value for techniques in isolation of viruses and development of many vaccines. Already, in the 1930's, medical doctors and scientists used tissue from voluntary pregnancy interruptions using defined tissue-derived cell lines. The Nobel Prize for Medicine in 1954 was awarded to American Immunologists who developed the polio vaccine based on cultures of human fetal cells. Since this time, many other necessary vaccines (rubella, chicken pox, hepatitis A, etc.) have been developed with the use of fetal cell lines including two primary human diploid cell lines and importantly, these fetal cell lines have been kept in frozen cell banks for decades and are still used safely today in manufacturing and production of subsequent cell banks [4348].

A "Cell Bank" is the stocked product of consistent cell cultures that are frozen into small vials that withstand long-term freezing in liquid nitrogen $\left(-165^{\circ} \mathrm{C}\right)$. The very first cells derived from tissue are designated as a parental cell bank and then the original organ donation is thus no longer necessary for derivative cell line development (Figure 2). The initial cell bank is frequently termed the Master Cell Bank (MCB) from which each vial can derive a Working Cell Bank (WCB). Whole cell bio-processing and adaptable procedures to Good Manufacturing 
Processes (GMP) make it possible to develop extensive MCB and WCB to facilitate thorough testing of the cells. Once MCB are accomplished, WCB can be produced to establish individual batches of treatments for high numbers of patients. Further, these cell banks can be tested completely for safety regarding sterility, pathogens, and adventitious agents and tumorigenicity.

The development of Master Cell Banks from cell sources provides a major advantage for the creation of a therapeutic biological agent (Figure 2). The least amount of cellular manipulation to provide enough cells for an extensive cell bank is also an advantage. It is important to mention that Good Manufacturing Practices are imposed to assure that cell cultures are not contaminated not only by virus, bacteria or molds but also by other cell lines. Even though this may seem difficult to imagine, it is more frequent in practice. When one submits a cell line into GMP processing, it is mandatory to do isotyping to assure the cellular origin [34,49].

\section{Organization of the progenitor cell therapy platform in Swit- zerland}

Already in 1991, the Swiss Government allowed the Fetal Transplantation Platform to be registered with the Department of Public Health and the program remained as such until 2007 when the new directions and Law of Transplantation took effect (Figure 2). Since 2008, the Fetal Transplantation Platform was accepted for the development of "Clinical Grade Tissues for Musculoskeletal Bioengineering" and registered with Swissmedic (Federal Program for Registration of Human and Veterinary Medicines and Transplants).

This possibility led to the Swiss Fetal Cell Therapy Platform that was developed for musculoskeletal tissues including skin, muscle, bone, cartilage, tendon and intervertebral disc [19,21,22,42,50-58] (Figure 3). Organ donations were available through a defined program where tissue from pregnancy interruption was made accessible when the mother had to interrupt her pregnancy for medical grounds. Under full written and oral informed consent, the mother donor could be accepted into the program for organ donation. The mother donor was assessed for specific viruses and infections by donating blood at the time of her pregnancy interruption and again after three months to assure

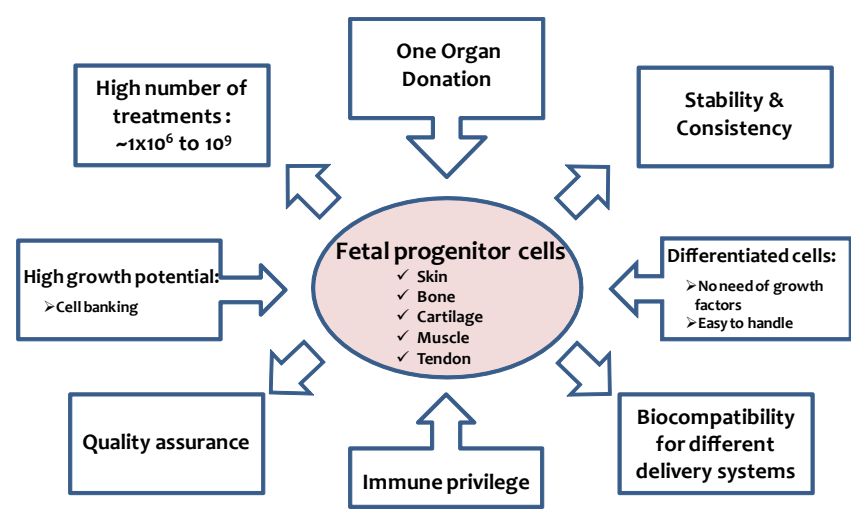

Figure 3: Progenitor fetal cell advantages.

From only one organ donation, stable sources of primary, diploid cells can be produced and stocked for long-term use for the clinic. Musculoskeletal tissues from skin, bone, cartilage, muscle, and tendon from only one parental cell bank have been shown to be stable, consistent under simplified culture conditions. Cells established in specific cell banking procedures are therefore easily screened for safety, have immune privilege and are biocompatible with many matrixes making them ideal candidates for cell therapy and delivery to patients allowing millions of treatments from one cell stock due to the high growth potential. that there was no sero-conversion. This period of time also allowed the mother donor to change her mind regarding her participation in the program. The tissue that had been donated could be put into primary culture immediately in the core facility for whole-cell bioprocessing developed in the University Hospital. The cells derived from the primary culture provided the parental cell banks necessary to submit to current Good Manufacturing Practice (cGMP) production of cell banks similar to those processes used in vaccine production since the 1950's.

Clinical cell banks have been fully developed for musculoskeletal tissues and skin which have allowed for progress in bioengineering of specific tissues that can be used for patient treatments. Regenerative medicine and techniques for efficient cellular expansion can perhaps help with the overall problem of organ donation availability.

A major advantage of the cells in this unique program with progenitor fetal cells is that they adapt particularly well to biomaterials allowing efficient and simple delivery to the patient (Figure 3 ). In our laboratory and in others, it has been shown that cells from donors (neonatal to adult) are not capable of efficient integration into various biomaterials and some biomaterials are in fact toxic to the cell. $\mathrm{Ng}$ et al. [59] have emphasized that physical characteristics of scaffolds, such as porosity and mechanical stability, are important for withstanding cell contraction forces and assuring a homogenous distribution of cells throughout the scaffold. It is true that the scaffold is very important for tissue engineering, but the cell type is most probably the limiting factor. We have seen that other fetal progenitor cell types adapt well to various biomaterials [50,59-61]. Progenitor skin cells have been used successfully in the clinic when associated with hemostatic dressings to date. This cell type can be easily integrated into these types of dressings to make biological bandages. There has been extensive research in the military sector for more functional hemostatic dressings to have lifesaving properties [62]. Biocompatibility of the new formulations could easily be done with skin progenitor cells for screening purposes and also for development of biologically effective bandages. Importantly, future bandages could be directed for specific antimicrobial activity especially for military use due to the variability of infectious agents in different regions such as Acinetobacter Baumanii in Iraq $[63,64]$.

Military implications of cellular therapy are multidimensional. A combat medic in a war zone might be equipped with tear-open progenitor skin impregnated bandages that can act as a battlefield prophylactic even before a full medical assessment is done. At a minimum the impregnated bandage can begin to rapidly heal multiple small cuts and abrasions that a soldier might have from being some distance from an IED while at the same time offering a firewall to targeted infectious agents. At a maximum this battlefield dressing can act as a topical biologic cover to avoid fluid loss while the injured soldier is transported to the rear for treatment. Triage aspects are also critical in a military environment. In a large burn casualty event, such as one would deal with in a bombing or IED, the field hospital will have more time for assessment because the progenitor skin impregnated dressing applied by the medic may not have to be immediately removed and its function as a topical biologic cover continues. A more careful renewal of the bandages might be the only treatment prior to transport to a major treatment center such as Landstuhl Regional Medical Center in Germany, where US military evacuees are transported to when they leave the operating theater.

Stretching the time of criticality for action through immediate battlefield application can have a huge impact on saving the lives of both soldiers and civilians caught in these horrendous war episodes. 
By developing consistent cell banks with fetal progenitor cells from only one organ donation, many of the risk factors can be eliminated for bringing safe and effective human cell-based therapies to the bedside.

\section{Recommendations}

With proper and efficient use of organs and cells, there can be many advances in new medical technology. Administrative policies can assure thorough management of essential aspects including scientific, ethical, legal, political, financial and regulatory to help establish guidelines and strategies to help at each level of development where pressures can exist and otherwise create significant barriers. Cell therapies are beginning to show great promise in medicine. As we have shown, the cell choice is therefore an important factor for simplifying the overall technique and bringing therapy rapidly to the patient. Thus, progenitor cells with their high expansion, simple culture conditions (do not require feeder layers or extensive growth factors for expansion which is a major reason for their consistency in scaling out), and low immunogenicity properties are ideal for whole-cell bioprocessing destined for cell therapy, tissue-engineering, and medicinal products. Additionally, they have already been used in safety clinical phase I \& II studies showing rapid and efficient tissue repair with minimal scarring. Delivery systems to afford better stocking and stability will be important milestones for biological products such as that recently used in Afghanistan [65]. Overall development needs to keep organ donations and patient safety a priority to assist physicians with the use of these new emerging therapies for patient care.

Bone marrow mesenchymal stem cells, foreskin cells and autologous cells are the cells sources widely explored for cellular therapies to date with high financing through the DOD. Other cell sources that are stable and that can be easily stocked should be given the same opportunity to explore full potential. Foreskin cells from newborns are an organ donation and are finally being widely used in tissue regeneration. Progenitor cells from fetal tissues have been shown to have more potent activity, can be stocked from only one single organ donation, and therefore more easily screened for security and safety.

\section{Specifically:}

- Optimize cell source for out-scaling and stability

- Optimize stocking of cells and central dispatch

- Optimize cell deposits with specific culture conditions for Research and Development

These cell types can be controlled through rigid federally registered Programs of Transplantation, can be deposited in Cell Depositories for research and merit attention for further development of new cell therapies and advanced plastic surgery techniques.

\section{Acknowledgement}

We would like to thank the Foundations S.A. N.T.E and Sandoz for valuable funding of the Swiss fetal cell transplantation program. We give a special thanks to Dr. Bob Krause, President of the Veterans National Recovery Center (VNRC, Des Moines, lowa, USA), for helpful suggestions and critical reading of the manuscript.

\section{References}

1. Manring MM, Hawk A, Calhoun JH, Anderson RC (2009) Treatment of war wounds: a historical review. Clin Orthop Relat Res 467: 2168-2191.

2. Taylor C, Jeffery S (2009) Management of military wounds in the modern era Wounds International 5: 50-58.

3. Khoo TL, Halim AS, Saad AZ, Dorai AA (2010) The application of glycerolpreserved skin allograft in the treatment of burn injuries: An analysis based on indications. Burns 36: 897-904.
4. Mack GS (2009) Osiris seals billion-dollar deal with Genzyme for cell therapy Nature Biotechnology 27: 106-107.

5. Newman RE, Yoo D, LeRoux MA, Danilkovitch-Miagkova A (2009) Treatment of inflammatory diseases with mesenchymal stem cells. Inflammation and AllergyDrug Targets 8: $110-123$

6. Kebriaei P, Isola L, Bahceci E, Holland K, Rowley S, et al. (2009) Adult human mesenchymal stem cells added to corticosteroid therapy for the treatment of acute Graft-versus-Host Disease. Biol Blood Marrow Transplant 15: 804-811.

7. Allison M (2009) Genzyme backs Osiris, despite Prachymal flop. Nature Biotechnology. 27: 966-977.

8. Raffoul W, Guerid S, Darwiche SE, Berger MM, Hayoz D, et al. (2013) Enhancement of wound healing using suspensions of autologous keratinocytes in platelet concentrates-a prospective randomized trial. Fibrogenesis and Tissue Repair

9. Neuhaus SJ, Wishaw K, Lelkens C (2010) Australian experience with frozen blood products on military operations. Med J Aust 192: 203-205.

10. Bichara DA, O'Sullivan NA, Pomerantseva I, Zhao X, Sundback CA, et al. (2012) The tissue-engineered auricle: past, present, and future. Tissue Eng Part B Rev 18: 51-61.

11. Reiffel AJ, Kafka C, Hernandez KA, Popa S, Perez JL, et al. (2013) High-fidelity tissue engineering of patient-specific auricles for reconstruction of pediatric microtia and other auricular deformities. PLoS ONE 8: e56506.

12. Badylak SF, Freytes DO, Gilbert TW (2009) Extracellular matrix as a biological scaffold material: structure and function. Acta Biomaterialia 5: 1-13.

13. Gravante G, Di Fede MC, Araco A, Grimaldi M, De Angelis B, et al. (2007) A randomized trial comparing ReCell system of epidermal cells delivery versus classic skin grafts for the treatment of deep partial thickness burns. Burns 33 : 966-972.

14. Wood FM, Giles N, Stevenson A, Rea S, Fear M (2012) Characterisation of the cell suspension harvested from the dermal epidermal junction using a ReCell kit. Burns 38: 44-51.

15. Centanni JM, Straseski JA, Wicks A, Hank JA, Rasmussen CA, et al. (2011) StrataGraft skin substitute is well-tolerated and is not acutely immunogenic in patients with traumatic wounds: results from a prospective, randomized, controlled dose escalation trial. Ann Surg 253: 673-683.

16. Marra KG, Rubin JP (2012) The potential of adipose-derived stem cells in craniofacial repair and regeneration. Birth Defects Res C Embryo Today 96 95-97

17. Addor V, Narring F, Michaud PA (2003) Abortion trends 1990-1999 in a Swiss region and determinants of abortion recurrence. Swiss Med Wkly 133: 219-226.

18. Wyss D, Wirthner D, Renteria SC, De Grandi P (2004) Les demandes d'interruption de grossesse de 1988 à 2002 au CHUV. Revue médicale Suisse. 2503: 1-8.

19. Applegate LA, Hirt-Burri N, Scaletta C, Bauren JF, Piolotti DP (2009) Bioengineering of Human Fetal Tissues For Clinical Use."Bioengineering: Principles, Methodologies and Applications" Nova Sciences Publishers, ISBN978-1-60741-7620, 133-152.

20. Yanow S (2013) It is time to integrate abortion into primary care. Am J Public Health 103: 14-16.

21. Applegate LA, Scaletta C, Hirt-Burri N, Raffoul W, Pioletti DP (2009) Whole-cell bioprocessing of human fetal cells for tissue engineering of skin. Skin Pharm Physiol 22: 63-73.

22. Applegate LA, Weber D, Simon J-P, Scaletta C, Hirt-Burri N, et al. (In Press) "Organ Donation and Whole-Cell Bioprocessing in the Swiss Fetal Progenitor Cell Transplantation Platform" In: Organ Donation and Organ Donors: Issues, Challenges and Perspectives, Nova Publications .

23. EU (2004) "Setting standards of quality and safety for the donation, procurement, testing, processing, preservation, storage and distribution of human tissues and cells," In: Parliament E, editor. Directive 2004/23/EC

24. EU (2006) "Implementing Directive 2004/23/EC of the European Parliament and of the Council as regards certain technical requirements for the donation, procurement and testing of human tissues and cells," In: Parliament E, editor Directive 2006/17/EC.

25. EU (2006) "Implementing Directive 2004/23/EC of the European Parliament 
and of the Council as regards traceability requirements, notification of serious adverse reactions and events and certain technical requirements for the coding processing, preservation, storage and distribution of human tissues and cells," In: Parliament E, editor. Directive 2006/86/EC.

26. FDA (2006) "Human cells, tissues, and cellular and tissue-based products," 21 CFR 1271

27. SwissMedics (2007) "Swiss Federal Council Transplantation Law" TxL SR 81021

28. PMP/ICH (2001) "Note for guidance on quality of biotechnological products: derivation and characterisation of cell substrates used for production of biotechnological/biological products" CPMP/ICH/294/95.

29. Rheinwald JG, Green H (1975) Serial cultivation of strains of human epidermal keratinocytes: the formation of keratinizing colonies from single cells. Cell 6 : 331-343.

30. Murry CE, Keller G (2008) Differentiation of embryonic stem cells to clinically relevant populations: lessons from embryonic development. Cell 132: 661-680.

31. Hohlfeld J, de Buys Roessingh A, Hirt-Burri N, Chaubert P, Gerber S, et al. (2005) Tissue-engineered fetal skin constructs for paediatric burns. Lancet 366 : 840-842.

32. de Buys Roessingh AS, Hohlfeld J, Scaletta C, Hirt-Burri N, Gerber S, et al (2006) Development, characterization and use of a fetal skin cell bank for tissue engineering in wound healing. Cell Transplant 15: 823-834

33. Quintin A, Hirt-Burri N, Scaletta C, Schizas C, Pioletti DP, et al. (2007) Consistency and safety of fetal cell banks for research and clinical use. Cell Transplatation 16: 675-684.

34. Capes-Davis A, Theodosopoulos G, Atkin I, Drexler HG, Kohara A et al. (2010) Check your cultures! A list of cross-contaminated or misidentified cell lines. Int J Cancer 127: 1-8

35. Oster H, Wilson DI, Hanley NA (2006) Human embryo and early fetus research. Clin Genet 70: 98-107.

36. Bhattacharya N (2004) Fetal cell/tissue therapy in adult disease: a new horizon in regenerative medicine. Clin Exp Obstet Gynecol 31: 167-173.

37. Montjovent MO, Bocelli-Tyndal, C, Scaletta C, Scherberich A, Martin I, et al (2009) In vitro characterization of immune-related properties of human fetal bone cells for potential tissue engineering applications. Tissue Engineering Part A 15: 1523-1532.

38. Quintin A, Schizas C, Scaletta C, Jaccoud S, Chapuis-Bernasconi C, et al. (2009) Human Fetal Spine as a source of cells for intervertebral disc regeneration. Journal of Molecular and Cellular Medicine 13: 1-12.

39. Hirt-Burri N, Scaletta C, Gerber S, Pioletti DP, Applegate LA (2008) Woundhealing gene family expression differences between fetal and foreskin cells used for bioengineered skin substitutes. Artif Organs 32: 509-518.

40. Ramelet A-A, Hirt-Burri N, Raffoul W, Scaletta C, Pioletti DP, et al. (2008) Chronic wound healing by fetal cell therapy may be explained by differentia gene profiling observed in fetal versus old skin cells. Exp Gerontol 44: 208-218.

41. Hirt-Burri N, Ramelet A-A, Raffoul W, de Buys Roessingh A, Scaletta C, et al (2011) Biologicals and fetal cell therapy for wound and scar management. ISRN Dermatol 2011: 549870.

42. Hirt-Burri N, de Buys Roessingh AS, Scaletta C, Gerber S, Pioletti DP, et al. (2008) Human muscular fetal cells: a potential cell source for muscular therapies. Pediatr Surg Int 24: 37-47.

43. Banatvala JE, Brown DWG (2004) Rubella. The Lancet 363: 1127-1137.

44. Jacobs JP, Jones CM, Baille JP (1970) Characteristics of a human diploid cell designated MRC-5. Nature 227: 168-170.

45. Graham FL, Smiley J, Russel WC, Nairn R (1977) Characteristics of a human cell line transformed by DNA from human adenovirus Type 5. J Gen Virol 36 $59-74$

46. Palache AM, Brands R, van Scharrenburg GJ (1997) Immunogenicity and

This article was originally published in a special issue, A World View Defense And Human Security handled by Editor(s). Dr. Rola Abdullah Ibrahim Al-Hoqail, University of Dammam, Saudi Arabia reactogenicity of influenza subunit vaccines produced in $\mathrm{MCDH}$ cells or fertilized chicken eggs. J Infect Dis 176: 520-523.

47. Patriarca PA (2007) Use of cell lines for the production of influenza virus vaccines an appraisal of technical, manufacturing and regulatory considerations: Initiative for Vaccine Research World Health Organization, Geneva, Swizerland.

48. Zimmerman RK (2004) Ethical analyses of vaccines grown in human cell strains derived from abortion: arguments and internet search. Vaccine 22 4238-4244.

49. Torsvik A, Røsland GV, Svendsen A, Molven A, Immervoll H, et al. (2010) Spontaneous malignant transformation of human mesenchymal stem cells reflects cross-contamination: putting the research field on track. Cancer Res 70: 6393-6396.

50. Tenorio DMH, Scaletta C, Jaccoud S, Hirt-Burri N, Pioletti DP, et al. (2011) Human fetal bone cells in delivery systems for bone engineering. J Tissue Eng Reg Med 5: 806-814.

51. Montjovent MO, Burri N, Mark S, Federici E, Scaletta C, et al. (2004) Fetal bone cells for tissue engineering. Bone 35: 1323-1333.

52. Montjovent M-O, Mathieu L, Schmoekel, H, Silke M, Bourban P-E, et al. (2007) Repair of critical size defects in the rat cranium using ceramic-reinforced PLA scaffolds obtained by supercritical gas foaming. J Biomed Mater Res A 83 $41-51$

53. Montjovent M-O, Silke M, Mathieu L, Scaletta C, Scherberich A, et al. (2008) Human Fetal Bone Cells Associated with Ceramic Reinforced PLA Scaffolds for Tissue Engineering. Bone 42: 554-564.

54. Pioletti DP, Montjovent MO, Zambelli P-Y, Applegate LA (2006) Bone tissue engineering using foetal cell therapy. Swiss Med Wkly 136: 557-560.

55. Krattinger N, Applegate LA, Pioletti DP, Caverzasio J (2011) Regulation of proliferation and differentiatioon of human fetal bone cells. European Cells Materials 21: 46-58.

56. Arvidson K, Abdallah BM, Applegate LA, Baldini N, Cenni E, et al. (2011) Bone regeneration and stem cells. J Cell Mol Med 15: 718-746.

57. Quintin A, Schizas C, Scaletta C, Jaccoud S, Applegate LA, Pioletti DP (2010) Plasticity of fetal cartilaginous cells. Cell Transplant 19: 1346-1357.

58. Darwiche S, Scaletta C, Raffoul W, Pioletti DP, Applegate LA (2012) Epiphysea chondroprogenitors provide a stable cell source for cartilage cell therapy. Cell Medicine 4: 23-32.

59. Ng KW, Khor HL, Hutmacher DW (2004) In vitro characterization of natural and synthetic dermal matrices cultured with human dermal fibroblasts. Biomaterials 25: 2807-2818.

60. Borcard F, Godinat A, Staedler D, Comas Blanco H, Dumont AL, et al. (2011) Covalent cell surface functionalization of human fetal osteoblasts for tissue engineering. Bioconjug Chem 22: 1422-1432.

61. Krauss Juillerat F, Borcard F, Staedler D, Scaletta C, Applegate LA, et al. (2012) Functionalization of microstructured open-porous bioceramic scaffolds with human fetal bone cells. Bioconjug Chemistry 23: 2278-2290.

62. Kheirabadi BS, Pusateri AE, Sondeen JL, Delgado AV (2004) Development of hemostatic dressing for use in military operations. Symposium on "Combat Casualty Care in Ground Based Tactical Situations: Trauma Technology and Emergency Medical Procedures. NATO/OTAN publication RTO-MP-HFM-109. $1-12$.

63. Kumar AR, Harshbarger R, Martin B (2010) Plastic surgery challenges in war wounded. Advances Wound Care. Chapter 12 ISBN13 978-1-934854-01-3.

64. Escamez M-J, Carretero M, Garcia M, Martinez-Santamaria L, Larcher F et al. (2010) Smart growth factor gene delivery for impaired wound healing Advances Wound Care. Chapter 62 ISBN13 978-1-934854-01-3.

65. Martinaud C, Ausset S, Deshayes AV, Cauet A, Damazeau N et al. (2011) Use of freese-dried plasma in French intensive care unit in Afghanistan. J Trauma 71: 1761-1765.

Citation: de Buys Roessingh A, Guerid S, Que Y, Berger M, Hirt-Burri N, et al. (2013) Cell Therapy Assistance in Reconstructive Surgery for Musculoskeletal Tissues Following Burn and Trauma: Swiss Cellular Transplantation Platform. J Def Manag S3: 003. doi:10.4172/2167-0374.S3-003 